\title{
コンクリート模擬環境における鋼材表面の電気化学的特性
}

\author{
望月紀 保*, 山田真澄*, 田中健一郎*, 金览 紘 征** \\ * 株式会社ナカボーテック技術開発研究所 \\ ** 秋田大学鉱山学部物質工学部
}

\section{Electrochemical Characteristics of a Steel Surface in Simulated Concrete Environments}

\author{
Noriyasu Mochizuki*, Masumi Yamada*, Kenichiro Tanaka* \\ and Hiroyuki Kaneko** \\ ${ }^{*}$ Research and Development Laboratory, Nakabohtech Corrosion Protection Co., Ltd. \\ ** Department of Materials Engineering and Applied Chemistory, Mining College, Akita University
}

A sodium chloride aqueous solution saturated with calcium hydroxide and its gel solution were used as simulated concretes for investigating electrochemical behavior of corroded steel in concrete. Results obtained are as follows :

(1) From cathodic polarization measurements of platinum in the gel solution, the gel solution was considered to act as an uniform diffusion layer for dissolved oxygen. The effect of concrete cover is evaluated experimentally by changing the thickness of the gel solution and theoretically by applying the finite element method.

(2) The polarization resistance of steel increased with decreasing cathodic potential until it reached its maximum at a specific potential, showing that the anodic resistance increases and the effect of cathodic protection can be estimated by this value.

(3) The changes of $\mathrm{pH}$ and chloride-ion concentration on the surface of steel were investigated after the polarization current had been applied on the steel. In the gel solution $\mathrm{pH}$ decreased with anodic polarization and increased with cathodic polarization, but in the aqueous solution $\mathrm{pH}$ was independent of polarization. In both the aqueous and gel solutions chloride-ion concentration was independent of polarization under the experimental conditions investigated. This phenomenon was explained by considering mass balance of chemical species in the solution close to the surface of steel.

Above results show that the gel solution is more adequate as an simulated concrete than the conventional simulated solutions.

Key words : concrete, steel, $\mathrm{Ca}(\mathrm{OH})_{2}, \mathrm{NaCl}$, gel solution, $\mathrm{pH}$, chloride ion, dissolved oxygen, oxygen diffusion, monitoring, AC impedance, DC polarization, cathodic protection, finite element method

\section{1. 緒言}

コンクリート中における鋼材の腐食は大きな社会問題 である。この問題を解決するために，すでに多くの各種 診断技術1) 3)，防食技術 ${ }^{4) \sim 6)}$ が開発発表されてきてい る。しかしながら，コンクリート中の鋼材表面が腐食防 食に伴ってどのような変化を受けるかといった環境評価

* T362 上尾市中新井 417-16 (417-16, Nakaarai, Ageo, 362 Japan)

** T010 秋田市手形学園町 1-1 (1-1, Tegatagakuencho, Akita, 010 Japan)
に関する事項は，コンクリート中に自在にセンサーを挿 入することが困難なためその場測定という観点での報告 は少なく，破壊検査による現象報告7),8)が主である。ま た, 電気防食適用条件下における防食効果の評価技 術4),5)に関しては経験則に偏重しているきらいがあり， 理論的検証に不十分な点が多い。

我々は, 上記問題の解明方法として取り扱いの複雑な コンクリート環境をあえて選ばず，適切な模擬環境を設 定することにより, より具体的に現象を把握することに 主眼をおいた。すなわち, $\mathrm{NaCl}$ を含む $\mathrm{Ca}(\mathrm{OH})_{2}$ 飽和 
水溶液, その水溶液を吸水性高分子でゲル化した水溶液 中で，腐食の進行過程やカソード防食の適用により鋼材 表面の電気化学的特性がどのように変化するかをその場 測定して追跡し, 診断評価に関する基礎的知見を得るこ とにした。

\section{2. 実験}

\section{1 センサー電極}

用いたセンサー電極は, $\mathrm{pH}$ ガラス電極と塩化物イオ ン検出用の銀/塩化銀電極である。 $\mathrm{pH}$ 電極は, 先端が $\phi 2.8 \mathrm{~mm}$ のガラス電極（東亜電波製）で上向き使用の 場合でも先端に空隙部が生じないように内部溶液をゲル 化したものである。塩化物イオン電極は， $\phi 3 \mathrm{~mm} \times 30$ $\mathrm{mm}$ の棒状の銀電極で側面をシールし，一端面を 0.1 $\mathrm{M}$ 塩酸中で電流密度 $1 \mathrm{~mA} / \mathrm{cm}^{2}$ で 30 分アノード電解す ることにより，表面に塩化銀の皮膜を付けた銀/塩化銀 電極である。なお，本実験では照合電極として $\mathrm{Hg} / \mathrm{HgO}$ 電極を用いたが，ゲル化した $\mathrm{Ca}(\mathrm{OH})_{2}$ 飽和 水溶液を内部溶液として持つ電極で, $192 \mathrm{mV}$ vs. NIIE $\left(25^{\circ} \mathrm{C}\right)$ である。本報告では電極電位はすべてこの $\mathrm{Hg} / \mathrm{HgO}$ 電極基準の值として示した。

\section{2 試 験 夜}

本試験には次の 3 種類のコンクリート模擬環境を用い た。すなわち，（1）モルタル，(2）塩分含有コンクリー 卜の間隙水を模擬した $\mathrm{Ca}(\mathrm{OH})_{2}$ 飽和 $\left.{ }^{9)}, 10\right)$ の $5 \% \mathrm{NaCl}$ 水溶液（以下模擬水溶液と称す)，(3) さらに（2）の 水溶液に而塭性吸水性高分子（日本触媒製アクアリック CS）を加えたゲル（以下ゲル化水溶液と称す）である。

モルタルは, セメント, 砂 (JIS Z 8801 角孔 $500 \mu \mathrm{m}$ のふるいにかけた川砂)，イオン交換水を重量比で 1 : $3: 0.6$ の割合で混合したものを打設後 1 昼夜大気放置 L, その後室温状態の水中で 1 调閒の養生後, 試験に 用いた。ゲル化水溶液は, 試験環境中のアルカリの全 当量值を一定とするために, $5 \% \mathrm{NaCl}$ 水溶液 $100 \mathrm{ml}$ に $\mathrm{Ca}(\mathrm{OH})_{2} 0.4 \mathrm{~g}$, 吸水性高分子 $8 \mathrm{~g}$ の配合比とした。

\section{3 試 験 体}

\section{3.1 直流 ·交流分極曲線測定試験体}

鋼材試験体は, JIS 規格 SS 400 を $10 \times 10 \times 2^{\mathrm{t}} \mathrm{mm}$ の 平板試片の一端から $6 \times 40 \times 2^{\mathrm{t}} \mathrm{mm}$ の短冊片がでている

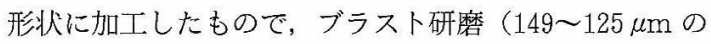
ガラスビーズ吹き付け）後，実験に用いた。SS 400 の 化学組成は, C : 0.04, Mn : 0.28, P : 0.01, S : 0.01 （wt\%）である。供試部は, 端部の $10 \times 10 \times 2 \mathrm{~mm}$ の両 面（側面も含む） $2.68 \mathrm{~cm}^{2}$ で, 残りはテフロンテープ にて被覆した。試験片を八丈島沖より採取した天然海水 中に約 1 週間浸漬させることによって全面腐食試験片を 作製し供試した。

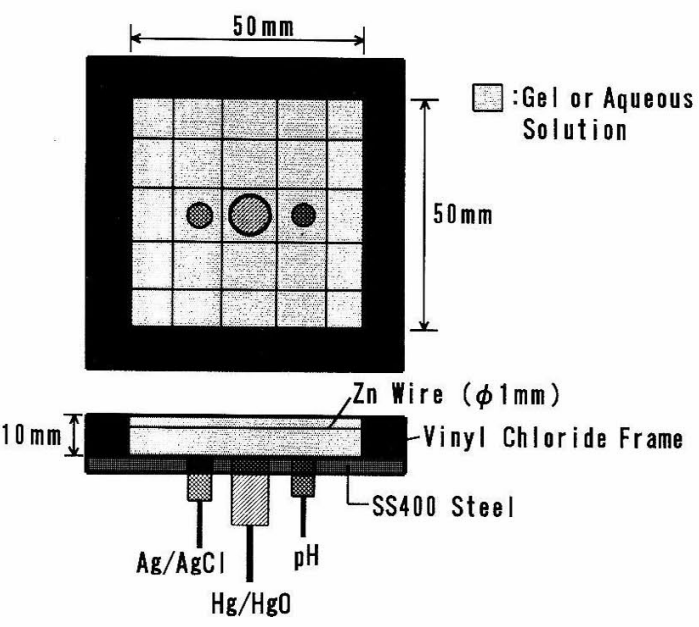

Fig. 1 Configuration of sensors and a zinc counter electrode in an electrolytic cell

白金試験体は, ゲル化水溶液, モル夕ルの場合, 塩化 ビニルプレート上に $10 \times 10 \times 1^{\mathrm{h}} \mathrm{mm}$ の窪地を持つホル ダーを製作し，その内部に $10 \times 10 \times 0.1^{\mathrm{t}} \mathrm{mm}$ の白金板 （供試面積 $1 \mathrm{~cm}^{2}$ ) を密着させ, 内部に当該試験液を充 填した。ゲル化水溶液の場合, 充填したゲル化水溶液上 をセルロース膜で覆うことによって固定した。模擬水溶 液においては，白金板の両面 $2 \mathrm{~cm}^{2}$ を供試面とした。

\subsection{2 センサー取り付け試験体}

ブラスト処理を施した $70 \times 70 \times 3^{\mathrm{t}} \mathrm{mm}$ の SS 400 平 板鋼材上の周囲を $10 \times 60 \times 10^{t} \mathrm{~mm}$ の塩化ビニル角材 で囲み，Fig. 1 に示すように内部 $(50 \times 50 \mathrm{~mm})$ を供 試面とした。供試面上には，センサー挿入口を開け，電 解電流の干渉を受けやすい銀/塩化銀電極は, 供試面下 $1 \mathrm{~mm}$ の位置に, 照合電極, ガラス電極は先端部が供 試面上に並ぶように下部より挿入して固定した。塩化ビ ニル角材には，上端面より $3 \mathrm{~mm}$ 下の部分に $10 \mathrm{~mm}$ 間 隔に $\phi 1.5 \mathrm{~mm}$ の穴を開け, 純度 $99.9 \%$ 以上の $\phi 1$ $\mathrm{mm}$ 亜鉛線を格子状に張り，対極とした。亜鉛線を対 極として用いたのは, 対極の電気化学反応が電解液中の $\mathrm{Cl}$-濃度に与える影響を極力少なくするためである。最 後に供試部以外の残余部分をエポキシ樹脂にて絶縁被覆 した。

\section{4 電気化学測定}

\subsection{1 腐食鋼材の交流インピーダンス測定}

アノード側とカソード側を JIS 規格 G 2 のガラス フィルターで分離したセパレートセル（以下セパレート セルと称す）に模擬水溶液またはゲル化水溶液を 630 $\mathrm{m} l$ 入れ，試料極として上記に記した腐食供試片を設置 した。定常状態が得られるように 1 日放置後, 大気開放 条件下において各種電位における交流インピーダンス測 


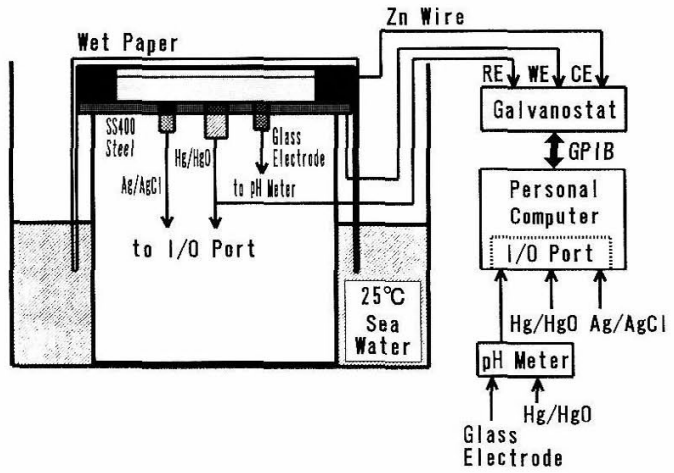

Fig. 2 Apparatus for monitoring electrochemical signals on a steel surface against corrosion and cathodic protection under simulated concrete media

定を実施した。対極は白金めっきチタン線，照合電極と して $\mathrm{Hg} / \mathrm{HgO}$ 電極を用い, 試験液は恒温槽にて $25^{\circ} \mathrm{C}$ に保持した。測定は，ポテンショスタット（北斗電工製 $\mathrm{HA}-501 \mathrm{G}$ ), と周波数応答解析器 (NF 回路ブロック 設計 S-5720 C) により, $10 \mathrm{kHz}$ から $0.1 \mathrm{mHz}$ まで, 設定電位に対し $\pm 10 \mathrm{mV}$ の交流電圧を印加する定電位 方式を用いた。なお, 自然電極電位以外の測定では 1 時 問の定電位電解の後, 周波数掃引を開始した。

\section{4.2 直流分極曲線測定}

本実験で取り上げた 3 種類の模擬環境下での溶存酸素 の拡散に与える影響を調べるため，先に示した白金電極 に対して模擬水溶液中でカソード分極曲線を測定した。 掃引速度は $20 \mathrm{mV} / \mathrm{min}$ である。

應食鋼材に対しては，交流インピーダンス測定值を直 流法の結果と比較するために, 交流インピーダンス測定 と同一の電極, 試験液を用いてカソード分極曲線を測定 した。測定は, 交流インピーダンス測定における実験装 置にファンクションジェネレータ（北斗電工 HB-105） を追加し, GPIB インターフェイスを介したパーソナル コンピュータ制御により掃引速度 $0.24 \mathrm{mV} / \mathrm{min}$ で実 施した。

\subsection{3 鋼材の腐食防食に伴う各種電極電位変化の測} 定

Fig. 2 に示すように, 台座を海水中に置き, 試験液 として模擬水溶液またはゲル化水溶液を充填したセン サー取り付け試験体をその上部に設置した。さらにゲル 化水溶液の場合は, 海洋環境に暴露されている $\mathrm{RC}$ 構 造物を模擬するために海水を含浸したペーパータオルで 試験体上部を覆い，端部は海水中に放置し常時試験体表

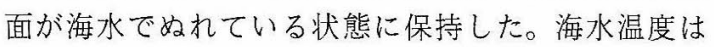
$25^{\circ} \mathrm{C}$ である。

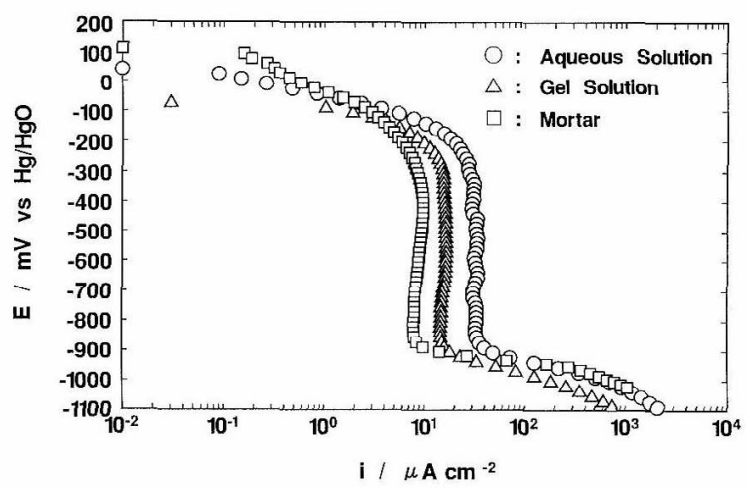

Fig. 3 Effect of simulated concrete media on the cathodic polarization curves of platinum measured in a $5 \% \mathrm{NaCl}$ solution saturated with $\mathrm{Ca}(\mathrm{OH})_{2}$ under the open air

亜鉛線を対極とし，鋼材を電解した時の各種センサー の応答をパーソナルコンピュータを用いて訳測した。

\section{3. 結果および考察}

\section{1 白金電極のカソード分極曲線による酸素拡散の} 評価

大気開放条件下におけるそれぞれの模擬環境下での白 金のカソード分極曲線を Fig. 3 に示す。ゲル化水溶液, モルタルにおける酸素の拡散限界電流密度は, 模擬水溶 液中のそれぞれおよそ $1 / 2 ， 1 / 4$ の值を示した。Gjorv ら ${ }^{11}$ や斎藤ら ${ }^{12}$ がモルタル全体を酸紊の拡散層として取 り报ったように，モルタル，ゲル化水溶液に対し，当該 試験環境全体を搪散層として报うと, 厚みは $1 \mathrm{~mm}$ と なり，ネルンストの拡散モデルを仮定して酸素拡散係数 を算出すると，それぞれ $8.3 \times 10^{-6}, 1.7 \times 10^{-5} \mathrm{~cm}^{2} / \mathrm{s}$ となり水溶液中における值 $\left(10^{-5} \text { オーダー }\right)^{13)}$ 之比較し ても大差のない結果となった。これは，模擬水溶液系の 拡散層の厚さを静止水溶液系で通常適用される $0.5 \mathrm{~mm}$ とすると，ゲル化水溶液環境は，模擬水溶液拡散層をそ のまま $1 \mathrm{~mm}$ 厚に拡張した系とみなすことができる。

ゲル化水溶液全体が均一な拡散層であるかどうかを調 べるために，Fig. 4 に示すようにゲル化水溶液を電解 セル中に充填し，定常的な拡散層が形成された時の払散 限界電流密度を電気化学的に計測し, 同一境界条件下で 溶存酸素の拡散速度を評価した 3 次元有限要素法 （FEM）上り求まる平均拡散限界電流密度と比較した。 電気化学的計測は, 対極の電気化学反応の影響を除くた めにセパレートセルを用いた。試料極側のセルに $\phi 100$ $\mathrm{mm} \times 80 \mathrm{~mm}$ のゲル化水溶液を充填し，その中央に 10 $\times 10 \times 0.1^{\mathrm{t}} \mathrm{mm}$ の白金板 $\left(2 \mathrm{~cm}^{2}\right)$ を配置した。対極 側のセルにも同様のゲル化水溶液と対極を置き, $25^{\circ} \mathrm{C}$, 


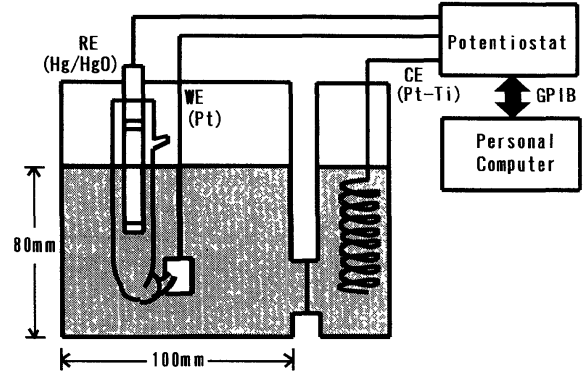

$\mathrm{Pt}$ is polarized at $-600 \mathrm{mV} v \mathrm{vs} . \mathrm{Hg} / \mathrm{Hg} 0$ in a gel solution at $25^{\circ} \mathrm{C}$

(a) Experimental Setup

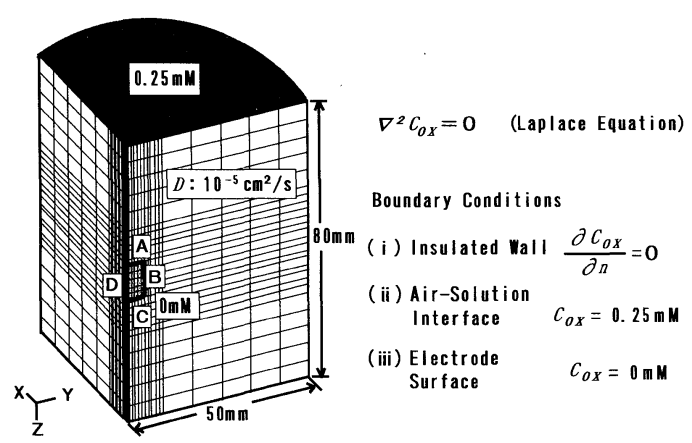

(b) Geometry and Boundary Conditions

Fig. 4 Electrochemical conditions and a theoretical model for analyzing the diffusion of dissolved oxygen in a gel solution

- $600 \mathrm{mV}$ における定電位電解を行い定常的な電解電流 密度を求めた。FEM 解析は系の対称性からセルの 1/4 を解析対象とした。境界条件は, 溶存酸素濃度 $C_{\mathrm{ox}}$ に対 し, 大気接触面の濃度を $0.25 \mathrm{mM}$, 白金表面の濃度を $0 \mathrm{mM}$, 拡散係数 $D$ は $10^{-5} \mathrm{~cm}^{2} / \mathrm{s}$ の一定值とした。 使用した FEM 解析ソフトは, 上村工業製「膜厚案内 人」である。

FEM 解析結果による白金表面の電流密度分布は Fig. 5 に示すように, 電極端部が高い值を示し電極表面全体 としては不均一であったが平均電流密度は 2.65 $\mu \mathrm{A} / \mathrm{cm}^{2}$ であった。一 $600 \mathrm{mV}$ における電解電流值は,

Fig. 6 に示すように電解 3 時間ほどで約 $3 \mu \mathrm{A} / \mathrm{cm}^{2}$ の定 常值を示し,この時点で電解セル中に定常的な濃度勾配 が形成されたと考えられる。両者の值はほぼ一致し，ゲ ル化水溶液全体が均一な拡散層として取り扱えることが 示された。したがって，ゲル化水溶液環境では，ゲル化 水溶液層の厚みを変えることによって, 任意の拡散限界 電流の設定が可能であると考えられる。

3.2 腐食鋼材の各種電極電位における交流インピー ダンスの変化

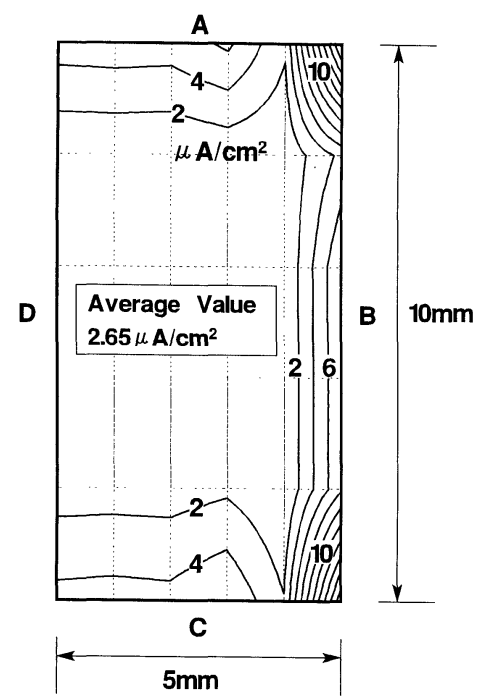

Fig. 5 Distribution of the current density of the electrode surface calculated for the model shown in Fig. 4 (The contour lines are shown at intervals of $2 \mu \mathrm{A} / \mathrm{cm}^{2}$ )

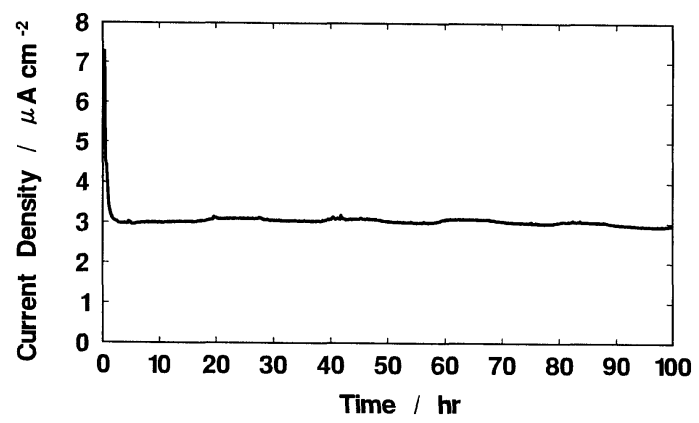

Fig. 6 Current density-time curve of platinum polarized at $-600 \mathrm{mV}$ vs. $\mathrm{Hg} / \mathrm{HgO}$ in a gel solution

腐食鋼の各種電極電位における交流インピーダンス特 性を模擬水溶液とゲル化水溶液において測定した結果を Fig. 7 に示す。

模擬水溶液の場合, Cole-Cole プロットによれば自然 電極電位では円弧であるが, $-700 \mathrm{mV}$ より高電位側で は低電位になるほど円弧は大きくなり歪んだ形を示し た。ゲル化水溶液のインピーダンス特性は, 模擬水溶液 のものと類似していることから反応過程も同様のものと 考えられる。ただし，ゲル化水溶液ではいずれの電位に おいても測定した低周波端で実数軸上への収束は認めら れなかった。また，低周波側においてはゲル化水溶液の 方が大きいインピーダンス值を示し, 両者の差が顕著に 現れた。

交流インピーダンス測定結果に対して電気化学的な意 

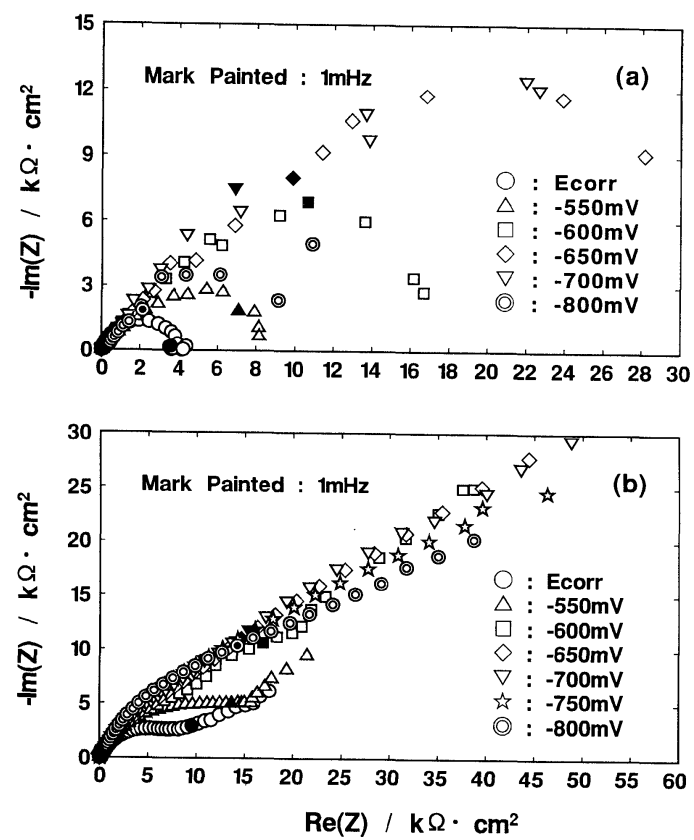

Fig. 7 AC impedance of a corroded steel measured at various electrode potentials under simulated concrete media.
(a) Aqueous Solution
(b) Gel Solution

味付けをする場合, 直流分極曲線の測定結果などを併用 することが有効である。

直流分極曲線の值は掃引速度によって変わるが, その 微分曲線が交流インピーダンスの極低周波におけるイン ピーダンスに対応することを考慮し， $0.24 \mathrm{mV} / \mathrm{min}$ の 遅い掃引速度で測定された模擬水溶液とゲル化水溶液中 のカソード分極曲線, またその微分值として求められる 分極抵抗を Fig. 8 に示す。得られた分極抵抗はゲル化 水溶液の方が大きく，いずれの環境においてもー650〜 $-700 \mathrm{mV}$ に極大值を示した。これは, Cole-Cole プ ロットの円弧の大きさの変化ともよく対応していた。

水流ら ${ }^{14)}$ は, カソード反応が酸素の拡散限界領域の下 ではカソード防食条件下であっても交流インピーダンス の極低周波端より求まるインピーダンスはアノード反応 抵抗を表し, 腐食速度の評価が可能であることを示し た。

自然腐食状態での腐食速度に対応する分極抵抗は, 周 波数の低下によって実数軸と交わるインピーダンスで, 本実験の場合, 模擬水溶液では Fig. 7 より $4 \mathrm{k} \Omega \cdot \mathrm{cm}^{2}$ である。ゲル化水溶液では Cole-Cole プロット上の円 弧の外挿值として $10 \mathrm{k} \Omega \cdot \mathrm{cm}^{2}$ とすると, これらの值は Sagues ${ }^{15)}$ が示す腐食速度換算係数 $26 \mathrm{mV}$ を用いて腐 食速度に換算するとそれぞれ $6.5 \mu \mathrm{A} / \mathrm{cm}^{2}, 2.6$ $\mu \mathrm{A} / \mathrm{cm}^{2}$ となる。この值は, Fig. 8 に示す同一環境下の

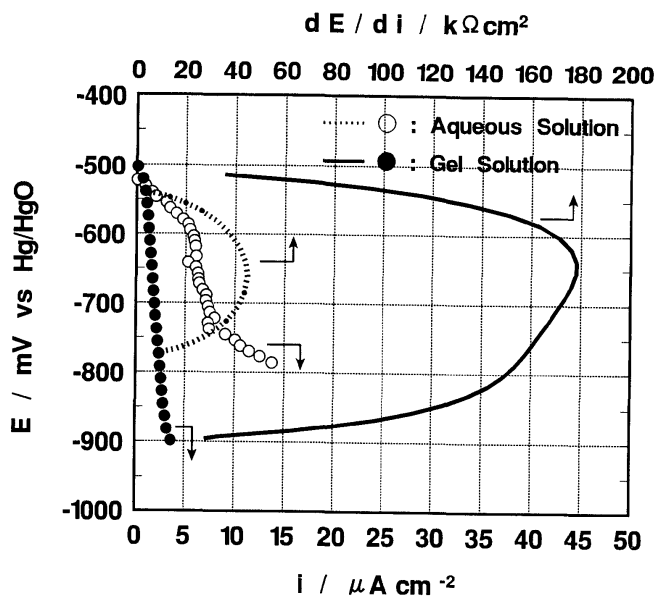

Fig. 8 Cathodic polarization curves and their differential curves for a corroded steel under simulated concrete media

カソード分極曲線の拡散限界電流密度とほぼ一致し, い ずれの模擬環境とも腐食速度が酸素の拡散限界電流に よって支配されていることがわかる。

したがって, Fig. 8 の微分曲線が示す極大值より高 電位側において，電位の低下とともに上昇した分極抵抗 は，アノード反応抵抗に対応するものと思われる。その 分極抵抗は，模擬水溶液，ゲル水溶液において，約 100 $\mathrm{mV}$ のカソード分極 ${ }^{16)}$ でそれぞれ $40 \mathrm{k} \Omega \cdot \mathrm{cm}^{2}, 170$ $\mathrm{k} \Omega \cdot \mathrm{cm}^{2}$ に増加している。これは先に示した自然腐食 速度と比較するといずれの模擬環境においても $1 / 10$ 近 い腐食速度の低減が得られたことになり, 本系の場合力 ソード防食下においても分極抵抗によりカソード防食効 果の評価が可能であることがわかった。

一方, $-650 \mathrm{mV} \sim-700 \mathrm{mV}$ より低電位側における 分極抵抗の減少は, 鋼材表面のさびが還元される反応 ${ }^{17)}$ が加わり, カソード反応の拡散限界条件が満足されなく なったためと思われる。

\section{3 鋼材の腐食防食に伴う各種電極電位の変化}

模擬水溶液およびゲル化水溶液中で鋼材を定電流電解 した時の鋼材表面における各種電気化学的パラメー夕の 経時変化を Fig. 9 に示す。

いずれの模擬環境においても，鋼材の電極電位は，10 $\mu \mathrm{A} / \mathrm{cm}^{2}$ のアノード電解により高電位方向に分極し，そ の後時間の経過とともに低下したものの全体的には - $500 \mathrm{mV} \sim-400 \mathrm{mV}$ の範囲内で推移した。また, 10 $\mu \mathrm{A} / \mathrm{cm}^{2}$ のカソード通電に切り替えた場合, 電位は徐々 に低下し, 最終的には, $-1100 \mathrm{mV}$ で定常的な電位を 示した。

$\mathrm{pH}$ は実験開始時には 12 ほどであったが，ゲル化水 溶液の場合アノード電解とともに徐々に低下し，3 時間 


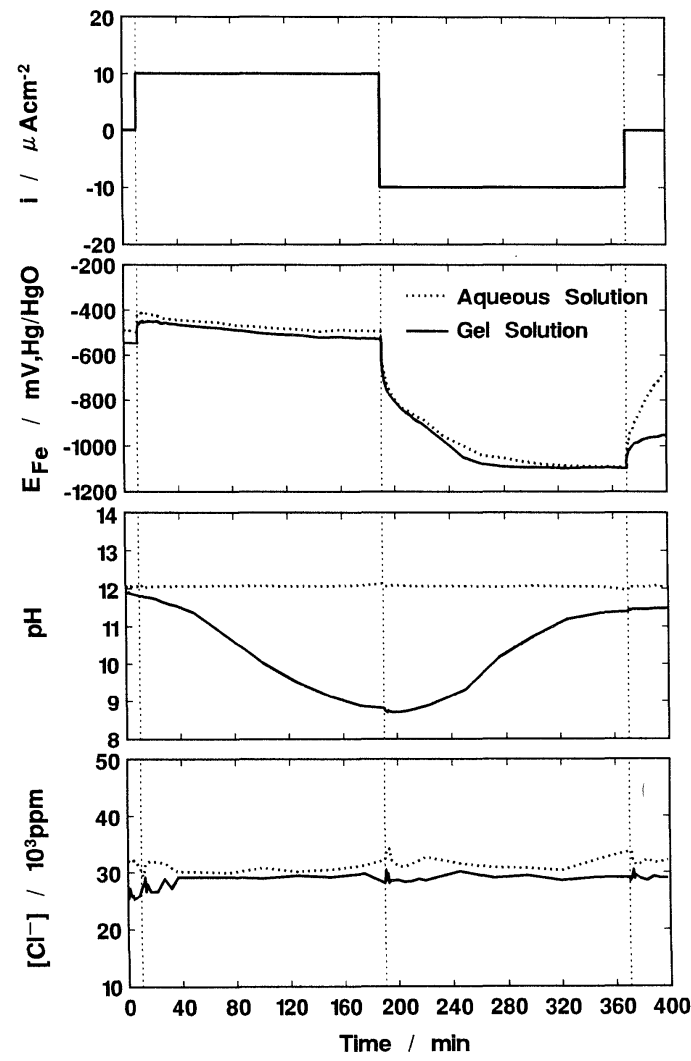

Fig. 9 Decay curves of electrochemical signals on a steel surface after applying anodic and cathodic currents under simulated concrete media

で 8.8 まで低下した。カソード電解へ切り替えた場合, $\mathrm{pH}$ の下降傾向はしばらく継続し，10 分ほど経過後上昇 傾向に転じ 3 時間後には, 実験開始時より，0.5 ほど低 い11.5 まで回復した。一方, 模擬水溶液においては, 終始当初の $\mathrm{pH}$ が維持され, 明確な $\mathrm{pH}$ 変化はなかっ た。

腐食によるアノード部の $\mathrm{pH}$ 低下の原因としては, $\mathrm{Fe}^{2+}$ あるいは鉄-塩化物錯体の加水分解が指摘されてい $ろ^{7)}$ 。

アルカリの中和反応を $\mathrm{Fe}^{2+}+2 \mathrm{OH}^{-} \longrightarrow \mathrm{Fe}(\mathrm{OH})_{2}$ と すると, 中和時での $\mathrm{pH}$ は $\mathrm{Fe}(\mathrm{OH})_{2}$ の解離平衡で決定 されるため 9.2 となる18)。したがって，Fig. 9 に示す ゲル化水溶液の実験結果は, $\mathrm{pH}$ センサー近傍のアルカ リ成分がほぼ中和されたことを意味する。本実験にお ける電解液量は $25 \mathrm{ml}$ であるから, 全アルカリ量は $\mathrm{Ca}(\mathrm{OH})_{2} 0.1 \mathrm{~g}$ より供給される $\mathrm{OH}^{-}$で $2.7 \mathrm{mmol}$ に相 当する。一方, アノード電解 $(0.245 \mathrm{~mA} \times 3 \mathrm{hr})$ によっ て生じた酸は, 溶出した $\mathrm{Fe}^{2+}$ と当量であるから $\mathrm{H}^{+}$と して $2.7 \times 10^{-2} \mathrm{mmol}$ となる。これは，全アルカリの
約 $1 \%$ 程度の量であり, 腐食によって生ずる酸に対して 近傍のごくわずかなアルカリで部分的な中和反応が完結 していることを示している。

カソード電解による $\mathrm{pH}$ の上昇は, 溶存酸素の還元に よる $\mathrm{OH}^{-}$の生成と思われるが, $\mathrm{pH}$ 上昇までに若干の 時間の遅れが生じたのは, 局部腐食環境下でのカソード 防食であるため, $\mathrm{pH}$ の低い腐食部に必ずしも十分な力 ソード電流が供給されなかったためと思われる。

塩化物イオンについて, 本実験では電解による濃度変 化はなかった。この原因について本実験のカソード電解 を例にとって考察する。電極表面から除去できる $\mathrm{Cl}^{-}$量 は, 電気泳動による減少量と減少の結果生じた濃度勾配 によって Cl-濃度を元に戻そうとする拡散に基づく移動 量とがつりあった時点で見かけ上 $\mathrm{Cl}^{-}$の移動は止まる。 拡散を $\mathrm{x}$ 軸方向の一次拡散, $\mathrm{Cl}^{-}$の輸率を一定とすると 次式が成立する。

$$
\begin{aligned}
& D\left(\frac{\partial C}{\partial x}\right) T S=\frac{t_{\mathrm{Cl}-I T}}{n F} \text { より } \\
& \left(\frac{\partial C}{\partial x}\right)=\left(\frac{t_{\mathrm{Cl}-}}{D F}\right) i
\end{aligned}
$$

ここで, $D$ : 拡散係数, $C$ : 濃度, $T$ : 通電時間, $S$ : 電極面積, $n$ : 電子数, $t_{\mathrm{Cl}^{-}}: \mathrm{Cl}^{-}$輸率, $I$ : 通電電流, $F:$ ファラデー定数, $i:$ 電流密度である。

脱塩効果は，(1)式より高電流密度ほど向上すること はもちろんであるが, 同一電流密度でもコンクリート中 における塩化物イオンの $D$ が小さく, $t_{\mathrm{Cl}^{-}}$が大きいほど 効果は大きくなることがわかる。

本実験の場合, $\mathrm{H}^{+}, \mathrm{Fe}^{2+}$ は濃度が小さいことから無 視すると, 電解において移動するイオン種は, $\mathrm{Na}^{+}$, $\mathrm{Ca}^{2+}, \mathrm{Cl}^{-}, \mathrm{OH}^{-}$- 4 種類である。模擬水溶液が $\mathrm{Ca}$ $(\mathrm{OH})_{2}$ 飽和 $5 \% \mathrm{NaCl}$ 水溶液であることから各イオンの 濃度は, $\left[\mathrm{Na}^{+}\right]=0.855 \mathrm{M},\left[\mathrm{Ca}^{2+}\right]=0.0126 \mathrm{M},\left[\mathrm{Cl}^{-}\right]$ $=0.855 \mathrm{M},\left[\mathrm{OH}^{-}\right]=0.025 \mathrm{M}$ となる。各イオンの当量 伝導率19) (無限希釈におけるデー夕を採用) により輸率 を計算すると, $t_{\mathrm{Cl}^{-}}=0.570$ を得る。

$$
D=10^{-5} \mathrm{~cm}^{2} / \mathrm{s}, \quad i=10 \mu \mathrm{A} / \mathrm{cm}^{2} \text { として (1)式に代入 }
$$
すると， $\partial C / \partial x=5.9 \times 10^{-3} \mathrm{M} / \mathrm{cm}=209 \mathrm{ppm} / \mathrm{cm}$ とな り, $1 \mathrm{~mm}$ の仮想カソード域を考えた時, 数 $10 \mathrm{ppm}$ （元の濃度の $1 / 1000$ 程度）の減少で定常状態になると 考えられることから塩化物イオン濃度変化は理論的にも 考えにくいことを示すことができた。

\section{4 コンクリート模擬環境としてのゲル化水溶液}

コンクリートは, セメント, 砂, 水の複雑な組成であ り, 一様な環境に設定することが困難なため, 再現性の よい実験結果を得ることが難しい。飽和水酸化カルシウ 厶水溶液は, 任意の溶存酸素濃度, $\mathrm{pH}, \mathrm{Cl}^{-}$濃度の設定 が可能である上に取り扱いの便利さから現在でもコンク 
リート模擬環境としてよく使われている。しかしなが ら, 物質の拡散が絡んだ現象の把握には薄い拡散層しか 持たない水溶液環境では限界があり, 取り扱いの容易な 厚い拡散層を持った模擬環境が必要とされる。水溶液に 代わる模擬環境が具備すべき条件は，従来の上記パラ メータの任意設定が可能なこと, 電気化学的測定が容易 でかつ安定してできることに加え，腐食環境全体を均一 な拡散層として取り扱えることである。

本研究において, 用いたゲル化水溶液は, 模擬水溶液 の性質を維持した均質なゲル媒体であることから上記条 件を満足したコンクリート模擬環境であることを示すこ とができた。適用に当って, $\mathrm{pH}, \mathrm{Cl}^{-}$濃度調製は模擬水 溶液で行う。酸素供給速度は, 拡散係数が模擬水溶液と 同等であることを考慮しかぶり厚さを変えることによっ て任意の酸素供給速度の環境を作ることが可能である が，実験に際しては白金の酸素拡散電流を測定しその系 の酸素供給速度を評価することが望ましい。また，ゲル 化水溶液の調製にあたっては, 空気を巻き込まないよう にすることが重要で, 模擬水溶液に吸水性高分子を徐々 に添加後, 水溶液の粘性が増加しないうちに試験槽に手 際よく流し込むことが必要である。実験が長期間にな り，期間中における模擬環境の含水率を一定に保つため には, Fig. 2 に示したような方法で模擬水溶液を常時 含浸したペーパータオルなどで覆うことによって模擬環 境の安定性を維持できる。さらに, 二酸化炭素による模 擬環境の中和が䯚念される場合は，ゲル化水溶液の模擬 環境上部にろ紙などを置きその上に $\mathrm{Ca}(\mathrm{OH})_{2}$ を散布す ることも有効と思われる。

\section{4. 結 論}

コンクリート中の腐食鋼の電気化学的挙動をより詳し く理解するため, $\mathrm{NaCl}$ を含む飽和 $\mathrm{Ca}(\mathrm{OH})_{2}$ 水溶液, およびその水溶液を吸水性高分子でゲル化したゲル化水 溶液のコンクリート模擬環境を用いて種々の電気化学的 特性を比較検討した。その結果,

（1）白金電極による酸素拡散の評価から，ゲル化水 溶液は，全体を拡散層として取り扱うことができ，ゲル 化水溶液の厚みを変えることによりコンクリートかぶり の効果を含めた腐食評価ができる。

（2）交流インピーダンスに対する電極電位の影響を 調べると電位の低下により分極抵抗は増大するが，特定
の電位で極大值を示した。電位の低下に伴う分極抵抗の 増大はアノード反応抵抗の増大と考えられ，この值によ りカソード防食条件下においても防食効果を評価でき る。

（3）鋼材の腐食防食に伴う電極表面の $\mathrm{pH}, \mathrm{Cl}^{-}$濃度 変化を調べると, ゲル化水溶液においてアノード電解に 伴う $\mathrm{pH}$ の低下, カソード電解による $\mathrm{pH}$ の上昇が確認 できた。 $\mathrm{Cl}^{-}$濃度変化は検出できなかったが，この現象 は $\mathrm{Cl}^{-}$の電気泳動之拡散による物質移動の釣り合いを考 えることにより説明できる。

これらの結果から総合的に判断すると, ゲル化水溶液 は従来の模擬水溶液よりもコンクリート模擬環境として 適切であることが明らかになった。

(Manuscript received March 31, 1997 ; in final form July 7,1997 )

\section{参 考 文 献}

1) 武若耕司 : コンクリート工学, 27，69 (1989).

2) A. A. Sagues : Corrosion 93, No.353 (1993).

3）日本コンクリート工学協会：コンクリート構造物 の耐久性診断に関するシンポジウム論文集, (1988).

4）日本コンクリート工学協会 : コンクリート構造物 の電気防食法研究委員会報告書, (1994).

5 ) 武若耕司 : コンクリート工学，30，16 (1989).

6 ) B. S. Wyatt: Corros. Sci., 35, 1601(1993).

7) Y. P. Virmani, W. R. Jones and D. H. Jones : Public Roads, 48, 96 (1984).

8 ) E. Otero, J. A. Gonzalez, S. Feliu, W. Lopez and C. Andrade : Proceeding of 11th International Corrosion Congress, p.2459 (1990).

9 ) D. A. Hausmann : Materials Protection, 8, 23 (1969).

10) J. F. Henriksen : Corros. Sci., 20, 1241(1980).

11) O. E. Gjorv, O. Vennesland and A. H. S. EIBusaidy : Mater. Perform., 12, 39 (1986).

12）斎藤博之, 高沢壽佳, 宮田恵守: 腐食防食 ' 92 , B-312，p.227 (1992).

13）小島 薰：防食技術，25，105（1976）.

14）水流 徹, 田 大熙, 春山志郎：防食技術, 36, 1 (1985)

15) A. A. Sagues : Corrosion 91, No.141 (1991).

16）日本コンクリート工学協会 : コンクリート構造物 の電気防食法研究委員会報告書, p.53 (1994).

17) D. C. Silverman : Corrosion, 38, 453 (1982).

18) M. Pourbaix : "Atlas of Electrochemical Equilibria in Aqueous Solutions", 310(1974).

19）玉虫伶太 :「電気化学」(第 1 版), p.297（1975）. 